\title{
A CONQUISTA DA FELICIDADE VIA FILOSOFIA: O EXEMPLO DE BOÉCIO
}

\author{
Idalgo José Sangalli ${ }^{I}$
}

\begin{abstract}
RESUMO: A análise visa a uma reflexão sobre ética e educação na obra De consolatione philosophiae, de Boécio. A partir da posição e atitude filosófica e de uma breve exposição geral do trabalho, procurase compreender o processo boeciano de busca da felicidade, exposto no Livro III. No diálogo entre a Filosofia e Boécio, é retomada a ideia de que todos os homens desejam alcançar o bem final identificado como felicidade. Perdidos na multiplicidade fragmentada dos bens exteriores das paixóes, os homens devem procurar, pelo caminho da filosofia e sem apelo à religiấo, o bem único e verdadeiro: Deus. A reflexão mostra o itinerário da vida humana e a necessidade de cada pessoa em "aprender a viver" uma vida ética, libertando-se das paixóes do corpo que adoecem a alma.
\end{abstract}

PALAVRAS-CHAVE: Ética. Felicidade. Bem supremo. Destino. Falsos bens.

\section{INTRODUÇÃo}

Ao pensar sobre a palavra felicidade, ou falar nela, imediatamente a associamos à condição existencial humana e a algo que muito desejamos. Por ela, elaboramos teorias, tomamos decisôes, agimos e fazemos coisas individual e coletivamente. Podemos pensá-la perguntando o que é, ou o que não é. Geralmente a relacionamos a condiçôes materiais privilegiadas, como ser admirado pelas multidóes, ter honra, poder, glória e dinheiro. Em momentos de crise, ou como terapia para vícios tradicionais, a exemplo de orgulho, vaidade, inveja, raiva etc., buscamos em manuais de autoajuda, muito em moda na sociedade contemporânea, a receita do bem-estar interior, da tranquilidade, da harmonia e da paz de espírito.

Todos esses sentimentos, aspiraçôes e pensamentos encobrem a situação e a posição que o homem ocupa no seu cotidiano e revelam a própria condição humana de seu tempo e no tempo, desde sempre na arena da luta entre paixão e razão. Isso está ligado ao projeto de construção do humano, pessoal ou coletivo, que cada geração, ao longo da evolução da história humana, formula, perguntando e tentando responder a questôes do tipo: "o que quero fazer

\footnotetext{
${ }^{1}$ Professor de Filosofia do Curso de Graduação em Filosofia e do PPG em Filosofia (Mestrado), da Universidade de Caxias do Sul (UCS). E-mail: ijsangal@ucs.br
} 
da vida?", "o que devo ser?", "como devo viver?", "aonde aspiro chegar, ou o que desejo que meus descendentes herdem para ter uma vida bem-sucedida e feliz?". No contexto atual de complexidade de informaçôes, de conhecimentos e de relaçóes, acrescidos pelo potencial (positivo e negativo) dos avanços tecnológicos e genéticos que fazem alguns conjecturarem sobre um futuro próximo de seres "transumanos", recolocam-se questôes antropológicas e a exigência da ética. Tais questôes envolvem um conjunto de domínios teóricopráticos de diversas áreas, as quais devem ser tratadas no discurso ético. Diante dos diversos tipos de ameaças, a sobrevivência das diferentes formas de vida de nosso tempo, é sabido que, dentre todos os saberes humanos necessários à vida, a educação e a ética são considerados basilares para a execução e realização de uma vida verdadeiramente humana, junto com as questóes sobre o meio ambiente e as tecnologias.

Aprendemos e nos educamos, a despeito das teorias de ensino e de aprendizagem tradicionais, a não sermos apenas levados ou conduzidos pela mão do mestre. Na verdade, a aprendizagem é sempre do próprio sujeito. Por nossa própria conta, podemos aprender experimentando, ou simplesmente fazendo analogias, ou ainda usando a memória e a imaginação, a partir do nosso passado e do conhecimento da narrativa do passado dos outros, desde as histórias contadas e escritas das fábulas infantis até a literatura especializada. A própria formação escolar está organizada no sentido de acompanhar o desenvolvimento cognitivo intelectual e o afetivo do educando. Assim, toda teoria educacional pressupóe e considera também como importante via formativa (formal ou informal) as leituras de obras clássicas, nas quais a experiência de outros modos de vida, as reflexóes e os problemas relatados ajudam o leitor estudante a aperfeiçoar as suas reflexóes e a avançar na formação e compreensão de si mesmo e de seu tempo. Em síntese, por diferentes maneiras, constrói-se a história da educação ou da formação do ser humano.

As teorias e práticas educacionais, em qualquer época, com seus condicionamentos sociais, econômicos e políticos, possuem em seus conceitos estruturantes concepçôes e abordagens filosóficas próprias de diferentes áreas de investigação. Normalmente, elas são inseridas e estudadas nos cursos superiores, nos conteúdos da disciplina Filosofia da Educação. Desses pressupostos, surgem questóes cruciais sobre a vida humana e suas interfaces, sendo que muitas são postas e repropostas por cada geração, tornando-se clássicas e não se esgotando, pois muitos desses problemas continuam os mesmos. Questóes de fundo, como as encontradas nas teorias e, principalmente, nas práticas 
educacionais, são aquelas com as quais os seres humanos sempre se deparam e para as quais precisam procurar respostas-guias e, o mais importante, respostas sobre quem somos e o sentido da vida.

Consideramos importante pensar na estreita relação, direta ou indireta, entre o passado e o presente, bem como nas questóes éticas e educacionais com base em sua aproximação com a história refletida da experiência humana. Buscar na produção literária do passado subsídios para compreender e aprofundar as reflexóes do presente é uma estratégia metodológico-educativa que faz jus à proposta da função social da história, defendida, por exemplo, pelo historiador Jacques Le Goff (2003, p. 26). Por sua vez, Japiassu (1997, p. 104) sustenta que "[a]s grandes interrogaçóes que os filósofos do passado fizeram, permanecem no presente: os homens de hoje continuam a se colocar problemas sobre eles mesmos, sobre a vida, sobre a sociedade, sobre a cultura, sobre o transcendente, etc., que constituem verdadeiros desafios à nossa atividade reflexiva”.

Nessa perspectiva, então, não parece valer a pena refletir sobre ética e educação, a partir dos acertos e erros dos antepassados? Se há uma obra que foi por quase mil anos uma das mais lidas no Ocidente ${ }^{2}$, perdendo somente para a Bíblia e para as regras monásticas de São Bento, essa obra é a De consolatione philosophiae. Não parece, por conseguinte, ser útil estudá-la, apesar de esquecida por muitos historiadores da educação e estudiosos de ética? Contudo, aqui o interesse está menos em compreender a influência, e não foi pouca, do pensamento helênico na filosofia e na educação do período medieval e mais em possibilitar que o leitor possa identificar as possíveis semelhanças e diferenças das necessidades e valores humanos de que precisamos para reter e compreender como guia, objetivando a "aprender a viver" na busca do ideal ético de uma vida humana serena e feliz.

O que estamos propondo é considerar a obra $A$ Consolação da Filosofia, do filósofo Severino Boécio, nascido em Roma (470) e executado em Pavia (IT), no ano de 525, como um modelo não só válido ou possível para uma reflexão ético-filosófica sobre o modo de vida humana, mas também como um modelo que, provavelmente, se apresenta como uma opção fecunda de reflexão ético-filosófica sobre o modo de vida humana. Boécio estudou em Roma e em

\footnotetext{
${ }^{2}$ Sobre a questáo da transmissão do texto e da contribuição doutrinal, veja-se a obra de COURCELLE, P. La consolation de Philosophie dans la tradition littéraire. Paris, 1967. Nessa obra, o erudito francês analisa as fontes diretas ou indiretas de Boécio para a composição do De Consolatione e a influência exercida fortemente até o século XII.
} 
Atenas e exerceu, no reinado de Teodorico (rei dos Ostrogodos), cargos públicos importantes, chegando a ser cônsul num período de decadência políticocultural do mundo greco-romano. ${ }^{3}$ No campo filosófico, realizou importantes traduçôes e deixou obras decisivas sobre temas de filosofia e de teologia. Vítima de calúnias nas atividades e relações consulares, foi enclausurado e, na prisão, escreveu a De consolatione philosophiae, sua última obra, numa perspectiva ética e educativa que é muito rica e que permite diferentes abordagens e aproximaçôes temático-metodológicas, influenciando geraçóes. Para além dos pressupostos e valores cristãos, dos elementos assimilados das filosofias helênicas e de seu estilo autobiográfico, a obra pode contribuir também para o processo de autoconhecimento e, assim, auxiliar a melhor responder às sempre atuais questóes e conselhos socráticos: "conhece-te a ti mesmo", "o cuidado de si" e "uma vida humana sem reflexão não é uma vida que vale a pena ser vivida”.

O que interessa à maioria dos mortais é agarrar-se ao ter (posses materiais e riquezas) como condição de ser feliz. Apostar exclusivamente nos bens exteriores, esquecendo os bens interiores da alma, é a melhor alternativa para uma vida humana feliz? Obviamente, não se trata de um simples desejo banal comum das pessoas de ter ou não ter. O que está em jogo aqui é a possibilidade da liberdade humana diante da aparência enganadora dos bens efêmeros que, em última análise, pressupóe o problema do "cuidado de si" e da "técnica de si” necessários para uma vida feliz. A questão é universal e será exatamente essa a inversão realizada por Boécio, seguindo os passos de outros filósofos (gregos) de privilegiar o próprio íntimo da alma humana, enquanto ser racional, ao recuperar valores morais e, mediante a reflexão ética, trilhar no caminho para a verdadeira felicidade. É uma reflexão puramente filosófica, empreendida por uma mente que pensa como cristáo, porém, surpreendentemente, em nenhum momento apela para a religião cristá. Certamente isso lhe valeu alguns pontos a menos perante as autoridades teológicas, embora tenha também legado escritos importantes sobre teologia cristã. ${ }^{4}$

Retomar o que Boécio entende por filosofia, por bem e, principalmente, por felicidade e o que esta é, se existe, onde pode ser encontrada e como é

\footnotetext{
${ }^{3}$ Para maiores detalhes sobre a vida de Boécio, vide KENNY, 2008, p. 37-40.

${ }^{4}$ Sobre os motivos de Boécio ter buscado consolo na Filosofia e não na fé cristã, muitos historiadores e intérpretes tentaram explicar e justificar, como fizeram G. Reale e D. Antiseri (1990, p. 474- 475) e também Gilson (1985, p. 137), entre outros. Todas essas tentativas são válidas, mas a questão continua em aberto.
} 
possível ao homem chegar até ela são os objetivos desta parcial reconstrução. ${ }^{5}$ Convém prestar atenção ao jogo tensional entre paixão e razão. Como questão de fundo, qual é a tarefa da filosofia, da ética e da própria educação pessoal, no contexto em que cada ser humano se encontra? E, para tal, faz-se necessário apontar alguns traços da plataforma na qual Boécio se movimenta e algumas ideias que mais o influenciaram. Essas relações serão tematizadas sequencialmente à reconstrução da exposição boeciana do Livro III, da $D e$ consolatione philosophiae.

Convém, para melhor compreender a importância e o alcance da proposta, fazer algumas considerações quanto à posição e à atitude filosófica de Boécio; depois, traçar a intenção e a estrutura geral da obra; e, finalmente, analisar o conteúdo do Livro III que trata da felicidade humana. Alertamos que, devido à riqueza e profundidade do pensamento de Boécio, nosso intento não passará de uma abordagem parcial, porém, suficiente para instigar novas leituras, investigaçôes e relaçôes, sobretudo para comparar com a questão ética e educacional, "na educação e cuidado de si", de nossa sociedade atual.

\section{Posiçấo E ATITUde FiLOSÓficA}

Notável tradutor, intermediário da cultura greco-romano-medieval, com cujas fontes teve o privilégio de estar em contato direto, Boécio deixou como herança para o Ocidente muito mais do que algumas traduçóes e obras importantes. É justamente tido como o último dos romanos e o primeiro dos escolásticos. Depois das contribuições de Cícero (século I) em disponibilizar obras essenciais para a educação da elite da sociedade romana, já em crise ético-política, Boécio acabou sendo o principal mediador da transmissão cultural das escolas gregas da antiguidade tardia e as da Idade Média Latina. A precisão e a competência de Boécio em fazer corresponder do grego para o latim os conceitos filosóficos fundamentais da filosofia de Platão e de Aristóteles mostram a formação e compreensão que teve do pensamento e da cultura greco-romana.

Como filósofo, "[...] no fundo era neoplatônico e admite expressamente tanto a Platão como a Aristóteles”, enfatiza Pieper (1979, p. 35). Tendo estudado

\footnotetext{
${ }^{5}$ Uma análise mais detalhada dos conceitos e das questốes presentes em toda a obra, especialmente referente à base antropológica pressuposta no ideal ético-filosófico de Boécio e a sua atualidade, pode ser encontrada no excelente trabalho recém-publicado por Cleber Duarte Coelho, O homem, o bem e a felicidade na consolação de Boécio (2014).
} 
nas escolas de Atenas do século V, Boécio se caracteriza filosoficamente por um ecletismo enciclopédico, como afirma Fraile (1965, p. 795), porque aproveitou o que considerava de melhor de cada escola filosófica, fossem elas platônicas, neoplatônicas, aristotélicas ou estoicas, sempre permeadas pela formação cristá. Não se limitou à atividade teorética de filósofo, pois buscou uma carreira na vida pública, dedicando-se à prática política. Além de ser profundo conhecedor da filosofia grega pagã e de exercer cargo político, foi um legítimo representante da classe dominante, possuidor das virtudes próprias do ideal de homem que se ocupava e se realizava pelo cultivo ao conhecimento e à sabedoria. Numa sociedade desorganizada e destruída politicamente, a vida política de Boécio foi truncada violentamente com a decisão de Teodorico, sem conseguir realizar o seu ideal de estabelecer o acordo e a unidade entre romanos e godos.

A importância de seu legado filosófico transcende a transposição linguística e marca, por muitos séculos, grande presença nos debates da Idade Média Latina, contribuindo para a formação e desenvolvimento do pensamento ocidental moderno. O problema dos universais, a questão do hilemorfismo universal e os escritos teológicos foram decisivos, assim como os comentários dos tratados de Lógica de Aristóteles possibilitaram a ele ser o professor de lógica da Idade Média até o surgimento das traduçóes, no século XIII, do Organon, de Aristóteles. Sua relevância pode ser avaliada pela obra de Pedro Abelardo, que analisou os comentários lógicos de Boécio. Essas obras e questôes, juntamente com o De consolatione philosophiae, que trata da questão da busca da felicidade, acompanhada de uma intensa reflexáo das condiçóes e dos limites antropológicos da natureza humana, são as principais contribuiçóes filosóficas para o pensamento escolástico e para a posteridade.

No entanto, um dos pontos que chama mais a atençáo do pensamento desse filósofo, tido como o primeiro escolástico (PIEPER, 1979, p. 44), é a relação entre a razão e a fé que caracteriza, em última análise, o próprio sentido do termo escolástica e a radicalidade metódica de alguns escritos de Boécio, em que a argumentação é puramente racional frente à verdade da fé. Essa concordância e até preferência da racionalidade diante das razóes da fé, mostradas pela primeira vez por Boécio, é a marca do método de ensino escolástico e o primeiro vestígio medieval de uma futura racionalidade moderna.

Sua noção e classificação da Filosofia deixou contribuiçôes para o ensino e a educação medieval, principalmente do esquema platônico-aristotélico de organização da ciência. Seguindo a noção platônica, a filosofia é, para Boécio, 
amor à Sabedoria. Nas palavras de Gilson (1985, p. 132), Sabedoria enquanto realidade,

[...] pensamento vivo, causa de todas as coisas, que subsiste em si mesmo e só necessita de si mesmo para subsistir. Ao iluminar o pensamento do homem, a Sabedoria o ilumina e o atrai para si pelo amor. A filosofia ou amor à Sabedoria pode, portanto, ser considerada indistintamente como a busca da Sabedoria, a busca de Deus ou o amor a Deus.

Quanto à sua classificação, a filosofia divide-se em uma parte especulativa (teórica) e uma ativa (prática), ambas ramificando-se em outras espécies, conforme os objetos que abordam. Todavia, não apresentaremos tais espécies aqui.

\section{Estrutura, conteúdo e conceito de filosofia na DE consolatione PHILOSOPHIAE}

Escrita na prisão, essa obra de estilo elegantemente literário, alternando verso e prosa, é uma marcante argumentação filosófica em forma de diálogo, como os de Platáo, aparecendo claramente a herança neoplatônica, juntamente com Aristóteles e o estoicismo. O diálogo se desenvolve ao longo dos seus cinco livros entre a personagem Filosofia e o prisioneiro Boécio. Apenas no Livro III é que a Filosofia faz a Fortuna (a roda da fortuna ou destino) falar. Cabe deixar claro que, como afirma Pieper (1979, p. 41), esses diálogos se dão entre “[...] o Boécio prisioneiro com o Boécio náo prisioneiro; fala com ele sua própria alma, que é livre enquanto mantém fixo o olhar na garantia divina do sentido total do mundo".

Nascida de uma tragédia pessoal, não é uma autobiografia no sentido estrito moderno, focado na experiência do indivíduo e sem se afastar do plano do cotidiano. Apesar do itinerário narrativo doloroso e libertador, é uma reflexão filosófica consigo mesmo, em que Boécio vai focalizar, também, temas pertencentes ao domínio teológico, mas sem lançar máo da teologia ou alusôes à Sagrada Escritura, e tudo isso usando, exclusivamente, sua memória. Segundo Gilson (1985, p. 137) e Fraile (1965, p. 802), aparece apenas um caso de citação bíblica, que era muito repetido por Santo Agostinho.

Ao ressaltar a validade da técnica antiga e medieval de memorização no processo de aprendizagem, Fumaroli (1998, p. xxiii) ressalta: 
O que Boécio nos ensina, com tanta autoridade hoje como no século VI, é que a única cultura fértil, oral ou escrita, é a que trazemos intimamente em nós, são os textos clássicos inesgotáveis inseminados na memória e cujas palavras tornam-se fontes vivas, à prova da tristeza, do sofrimento, da morte. O resto, de fato, é "literatura".

A obra representa, além da sabedoria estoica frente à adversidade, ao infortúnio e à dor, a própria sabedoria cristã que parece estimular a resignação e a confiança na Providência, para superar as investidas do mal no mundo. $\mathrm{O}$ pano de fundo é a relaçáo bem versus mal, que de certa forma corresponde ao ser e não ser dos pré-socráticos. A questão fundamental de Boécio é como explicar que o curso das coisas humanas esteja tão pouco de acordo com a ordem perfeita que reina na natureza. E, da resposta encontrada, avança para esta outra questão: se Deus existe, de onde vêm a injustiça e o mal que governam as ações dos homens? Até hoje estamos procurando respostas. Boécio procura as suas a partir da consideração de duas vidas ou dois mundos, no sentido de um interior e de um exterior, sempre em constante tensão, nos quais procura conciliar a Providência e o Destino. Em outras palavras, é a relação da pré-ciência divina e de seu governo universal sobre todas as coisas com a liberdade humana.

No fundo, é a condição humana, a estrutura antropológica do homem e a necessária aceitação dessa condição que podem ser reconhecidas e que possibilitam a tranquilidade de espírito que todo o ser humano procura. Aceitar tal condição humana e ser feliz implica voltar-se para a interioridade, algo válido ainda hoje. Buscar na alma a felicidade, conforme o ideal neoplatônico, e não exclusivamente nas coisas exteriores procuradas pela grande maioria dos seres humanos é o que sugere Boécio. Tarefa humana difícil, especialmente se considerarmos os poderosos estímulos sobre os sentidos produzidos pela tecnociência contemporânea, aos quais somos submetidos na atual sociedade globalizada. Não podemos esquecer quem somos.

Apesar das diversas maneiras de leitura da obra, só é possível ouvir a própria vox humana de Boécio, como destaca Pieper, se escutarmos com a própria alma, sem nos determos no imediatamente dito. Com isso, revela-se o homem prostrado, que tudo ou quase tudo perdeu e "[...] intenciona assegurar o seu último saber". Lança mão das contribuiçóes teóricas precedentes, salienta ainda Pieper (1979, p. 38), para responder "a uma eterna pergunta humana" 
acerca do sentido da vida. No diálogo, a personagem Filosofia obrigará o seu antigo discípulo a tornar-se novamente aluno. Ele precisará expulsar de si mesmo a dor de homem, outrora político e poderoso e agora caído em desgraça, devido à revolta contra a injustiça e também à angústia de estar privado de seus bens, de seus familiares e amigos, além da iminência de perder igualmente a própria vida. Assim, a argumentação e as respostas não serão da religião cristá, mas da filosofia, revelando uma terapia da própria alma em face das dificuldades da vida.

Quais são os temas tratados ao longo da obra? No primeiro dos cinco Livros que a compóem, a Filosofia vai mostrar a Boécio a origem e a natureza de seu mal. Boécio encontra-se cansado, desesperado, infeliz com a situação a que se encontra submetido, e que está longe de ser um caso isolado, mesmo se confrontada com os modos de vida contemporâneos. Ele começa com o poema de lamento e expóe os motivos de sua condição. Diante de suas lamentações, surge a Filosofia, explica Boécio (Livro I, prosa 2), em forma de "[...] uma mulher que inspirava respeito pelo seu porte: seus olhos estavam em flamas e revelavam uma clarividência sobre-humana [...]". Ao ver que o seu doente discípulo está rodeado pelas Musas da Poesia, ela as expulsa. A presença da Filosofia é um destaque positivo da confiança na racionalidade humana que, de alguma forma, participa da racionalidade divina, podendo conquistar a sabedoria e superar a ignorância alimentada pelos caprichos da Fortuna.

Ao mencionar as meretrizes do teatro, o autor faz uma alusão à argumentação da Poesia, conforme a crítica de Platão ao discurso poético, retórico, feito de aparências, um mero imitar que conduz ao engano, o qual seduz e aprisiona as escolhas no desejo de prazeres e bens efêmeros. É o reino das paixôes (pathos), interpretado platonicamente como sinônimo de doença. Isso será descartado em favor da argumentação racional, do exercício dialético como método de exposição para dissertar sobre a filosofia e, assim, livrar-se das paixóes pelo uso da razão. Será o velho e, de certa maneira, sempre atual antídoto para livrar-se dessa condiçáo alienante e dependente das paixôes e dos meros desejos materiais e artificiais. Isso talvez possa ser válido também para confrontar a sofisticada manipulação midiática de nosso tempo.

Nesse ponto, a Filosofia indica que seu erro foi ter esquecido, tal qual alguém que está fraco e doente, qual é o verdadeiro fim do homem e, assim, estimula o seu discípulo Boécio a falar e a recordar a origem e natureza de seu mal. Ela o consola, citando exemplos de outros discípulos (filósofos) que também sofreram injustiças e receitando conselhos estoicos para os seus males. É o início 
do diagnóstico e do tratamento de algo patológico. Entretanto, o termo grego pathos, que foi compreendido como um afeto mórbido que pode ser controlado, indica a condição passional do ser humano que constitui parte daquilo que entendemos abranger o campo da ética. Veremos, no conjunto do texto, que Boécio parece contemplar os dois conceitos de pathos: começa como um estado patológico e, no decorrer da argumentação, entra a dimensão passional.

Ainda no Livro I, a Filosofia recorda os sofrimentos de Sócrates e encoraja Boécio a um desprendimento socrático em relação aos assuntos do mundo. A Filosofia fez Boécio compreender que ele se esqueceu de si mesmo e que o governo do mundo não está entregue à cegueira do acaso ou simplesmente ao destino que domina a vida humana, mas à divina Razão e, por isso, nada deve temer.

No Livro II, a Filosofia conclama seu discípulo a conformar-se com as vicissitudes da Fortuna, que lhe deu bens na vida; e náo deveria se queixar, uma vez que ela também o despojou de bens fictícios. É o destino da vida humana ter/perder os bens e pensar, erradamente, que a felicidade reside na sua posse. É um retrato perfeito igualmente das expectativas e anseios que a maioria das pessoas assume, na vida atual. A Fortuna, como era chamada pelos romanos (resultando mais tarde na popular alegoria e nos jogos da roda da fortuna), é presença dominante também em nossa sociedade consumista. Essas duas formas (ter e perder) são o destino, que é a lei de sucessão das coisas no tempo. E o destino está na via oposta da Filosofia, que é a sabedoria racional. A Filosofia mostra a Boécio que o problema do homem está em escolher quem o vai dominar, isto é: o destino (Fortuna) ou a sabedoria racional. Por ter recebido da Fortuna muitos benefícios, que o desviaram dos verdadeiros bens, ele deve também aceitar os reveses que ela lhe trouxe, pois podem ajudar Boécio a voltar aos verdadeiros valores.

No Livro III, núcleo de toda a obra, a Filosofia faz Boécio ver a essência da felicidade, terminando por identificá-la com o Soberano Bem, que é Deus. É a parte a ser trabalhada no próximo tópico de nosso estudo.

Quanto ao Livro IV, Boécio examina como Deus rege o mundo e expóe suas explicaçóes sobre a Providência e o Destino. Questiona a conciliaçáo da existência de Deus com a do mal e por que os maus permanecem impunes e prosperam. Demonstra que a prosperidade dos maus é apenas aparente. A Filosofia vai mostrar que os maus são infelizes, porque se transformam em animais. 
E, no último Livro, é abordado o problema da Providência de Deus, e a tentativa de harmonizá-la com o livre-arbítrio do homem, que é a questão da liberdade. Num mundo governado por Deus, ele questiona se poderia existir algo como a sorte ou o acaso. E o final da obra? A Filosofia termina bruscamente, sem conclusão. Isto é, Boécio para de escrever nos pedaços de tábua fornecidos por Símaco, quando o visitava, pois a morte chegara.

\section{O PROCESSO DA BUSCA DA FELICIDADE humana (LIVRo III)}

Após ter concedido à Fortuna, através da personagem Filosofia, o direito de se autodefender e de ter ouvido dela que há bens enganosos e bens verdadeiros, assim como há uma fortuna propícia e outra adversa, Boécio leva a cabo a sua busca da verdadeira felicidade, dando-se conta de que, até então, embora sonhasse com ela, lidara apenas com meros simulacros. Boécio classifica como sombras tudo o que os humanos costumam tomar por felicidade e fornece um procedimento formal para distinguir o que é a verdadeira felicidade.

Em seu diálogo com a Filosofia, portanto, ele é levado, pouco a pouco, a desvencilhar--se das lembranças inoportunas da vida que outrora tivera, repleta de aparências, em que julgava e tomava a riqueza, a honra, o poder, a glória e o prazer como a verdadeira felicidade. Mais sereno frente à sua condição, ouve a argumentação da Filosofia, que pretende consolá-lo e leválo a perceber o que seja a verdadeira felicidade, através da demonstração da incapacidade dos bens externos, das coisas temporais, como condiçóes para satisfazer o desejo da alma humana. A argumentação desenvolvida é pela via negativa, que vai da prosa 3 até o poema 16, do Livro III, seguindo, assim, o método de exclusão usado por Aristóteles na Ética a Nicômaco. Com isso, aponta aquilo que a felicidade não é, embora facilmente possa ser atestado, ainda hoje, que isso seja tomado, pela maioria dos homens, como se fosse a verdadeira felicidade.

No início da prosa 3 do Livro III, a Filosofia apresenta a Boécio alguns conceitos tradicionais e a definição de felicidade. Sua fala começa de certa maneira parafraseando as primeiras linhas da Ética a Nicômaco (I 1 1094a), afirmando que " $[\ldots]$ os mortais se dirigem pelos mais diversos caminhos. Com efeito, todos os homens têm em si o desejo inato do bem verdadeiro, mas os erros de sua ignorância desviam-nos para falsos bens". Tudo o que buscamos e queremos, mesmo que seja por vias tortuosas e inferiores e nem sempre 
conscientes, é atingir o fim perfeito. Não visamos a algo além, já que esse fim se basta a si mesmo, evitando uma regressão ao infinito. Enfatizava Aristóteles (EN I 1 1094a) "[...] que o bem é aquilo a que todas as coisas visam. [...] evidentemente tal finalidade (que desejamos) deve ser o bem e o melhor dos bens".

É preciso falar do bem para, em seguida, falar da felicidade, que “[...] é o maior de todos os bens e encerra em si todos os demais". Todavia, às sombras dessa concepção teleológica, a definição de felicidade consiste num "Status bonorum omnium congregatione perfectus" (Livro III, prosa 3). Essa definição boeciana, a felicidade consiste num estado perfeito pela congregação de todos os bens, se tornará clássica e será repetida pelos escolásticos, em especial por Santo Tomás de Aquino e pelos seguidores do tomismo.

Aqui, uma pergunta se impóe à mercê dessa definição de felicidade: é possível atingir esse estado perfeito, em que todos os bens se encontram reunidos? Se a resposta for buscada na existência cotidiana das coisas temporais, por conseguinte, passageiras, mutáveis, imperfeitas, contingentes e artificiais, parece, de saída, algo impossível de alcançar. Todos é um termo que, na linguagem lógica, não admite exceções. Mas a distinção de dois mundos e o locus em que a felicidade deve ser procurada vai revelar o vigor e a força de tal definição de felicidade, mesmo com as exigências formais de finalidade, completude e perfeição.

Continuando a argumentação, a Filosofia vai apontar que as aspirações humanas levam muitas vezes a considerar como bons alguns falsos bens e, nesse caso, o agir errado e vicioso acontece. Há um desejo natural, daí inato, para o bem. Porém, esse ideal socrático náo é suficiente para garantir que o caminho será trilhado virtuosamente e isento de tropeços, porquanto a vontade humana é livre na escolha. $\mathrm{O}$ erro provocado pela escolha, ao considerar os bens do mundo sensível como lugar da felicidade, remete ao mau uso da faculdade do intelecto, devido à ignorância e, principalmente, ao grande apego aos falsos bens materiais os quais geram profundas inquietaçôes e ansiedades na alma humana, em funçáo de sua instabilidade e por náo cumprirem o que prometem. Se, pela vontade livre, a preferência recai sobre um bem determinado, julgado como sendo o bem supremo e, portanto, como sendo felicidade, então é compreensível que cada homem ajuíze que a felicidade está naquele bem escolhido entre os demais. 
O engano ou erro é caracterizado pela procura direta de um dos bens, como a riqueza, a honra, o poder, a glória e os prazeres, em função daquilo que prometem. Ou, ainda, por fazer de alguns desses bens meios para chegar a outros. Existem, contudo, bens que "[...] não pertencem aos bens da fortuna, mas aos da virtude" (Livro III, prosa 2), como os verdadeiros amigos, a mulher e os filhos. Tal afirmativa pode ser entendida, aqui, como uma alusão ao sogro (Símaco), à esposa e aos próprios filhos. A Filosofia tenta convencer Boécio de que não é infeliz de todo, já que conserva esses seus melhores bens. Por outro lado, fica evidente a referência feita aos falsos amigos que, na hora da desgraça, o abandonaram. Essa menção é mais bem apresentada no Livro II, prosa 5.

Ao vislumbrar as imagens dos falsos bens que prometem a felicidade humana e a circunstância de que, seguindo a interpretação hedonista de Boécio, nas palavras da Filosofia, Epicuro elegeu o prazer como o bem maior, é o início de uma nítida referência ao mundo sensível e, sobretudo, à teoria da reminiscência platônica a qual voltará a aparecer no verso final da prosa 13. A frase decisiva (Livro III, prosa 3) é: "Mas volto a considerar os esforços daqueles cuja alma náo cessa de procurar o que é bom para si, mesmo se sua escolha o induz ao erro; tal como o ébrio, sua alma não encontra o caminho de casa”. É a realidade de muitas pessoas também na nossa atual sociedade da informação que estão, assim como o prisioneiro Boécio, mergulhadas no mundo sensível das aparências, considerando-o, via percepção sensível, como a verdadeira realidade, ou seja, o lugar do bem e da felicidade, do qual sua alma está à procura, já que é algo inato no homem. No entanto, ele não sabe como e por onde retornar; afinal, os falsos bens ofuscam e confundem a sua memória.

No esforço de obter a posse e fruição daquelas coisas que causam deleite, ao alcançá-las, os homens experimentarão o sentimento de autossuficiência, de serem respeitados, de serem poderosos, de serem famosos e, consequentemente, felizes. Tudo isso demonstra que, mesmo por caminhos e modos diferentes, todos os humanos visam ao mesmo fim. Esse fim é um bem no qual todos concordam em apreendê-lo como fim, mesmo que, pela vontade livre humana, resulte na diversidade de opiniôes, ao determinar que tipo de vida o realiza. Porém, há uma "força da natureza", isto é, uma força determinada por Deus que indica esse fim, essa condição teleológica, que aponta para o bem. Boécio só vai usar o conceito de Deus após a poesia 12, embora aqui se possa chegar a tal conclusão. 
Ao iniciar a prosa 5, que trata da riqueza, a Filosofia volta a falar da inclinação para o bem verdadeiro e deixa claro o que foi exposto:

\begin{abstract}
Vós também, criaturas terrestres, mesmo se a concebeis de maneira imprecisa, podeis ver em sonhos vossa origem e entrever o verdadeiro fim que é a felicidade através de uma percepção que, embora náo seja clara, tem ao menos o mérito de existir; e é por essa razão que, de um lado, vossa inclinação natural vos leva ao verdadeiro bem, mas, de outro, vossa cegueira quanto aos seus inumeráveis aspectos afasta-vos dele.
\end{abstract}

Nos próximos passos, a Filosofia vai mostrar a Boécio o lado negativo de cada um dos falsos bens, e a necessidade que surge, a partir da não confirmação, de realizar aquilo que prometem. Vai ficar claro que os bens exteriores náo tornam o homem feliz, nem mesmo na reuniáo de todos eles por um só homem.

Nessa prosa 5, é praticamente o único momento frente aos demais bens falsos tratados em que Boécio dialoga com a Filosofia. Isso talvez pela condição de vida luxuosa que levara no passado, mas com posterior perda de riquezas. Boécio concorda que a riqueza traz perturbação e inquietude e "[...] não pode fazer com que um homem não tenha necessidade de algo, que é o que ela promete". Mesmo tendo-a, ficamos na ansiedade, no temor de tudo perder, e não há garantias de isso não acontecer só porque assim o queremos. Nessa carência do desejado, revela-se que tal posse não é autossuficiente. Mas as riquezas também fazem o outro empobrecer.

Para reaver as riquezas ou mantê-las, lança-se mão dos pleitos judiciais, como sublinha Boécio, e da segurança de outros. Essa dependência de outras pessoas para guardar e proteger os ricos evidencia, na verdade, uma nova necessidade. Ao buscar a autossuficiência através da riqueza, manifestase, como que num movimento dialético, o trabalho do negativo, em que as necessidades a serem suprimidas pela riqueza são algo impossível. E a Filosofia conclui, perguntando: "Assim, se as riquezas, longe de evitarem a necessidade, criam sua própria necessidade, como poderíeis crer que elas podem oferecer uma garantia de independência?” (prosa 5).

Na prosa 7, a Filosofia vai falar dos cargos que são objetivados, já que prometem honra e respeito. Os cargos aumentam a desonra, os vícios e as maldades das pessoas indignas deles, além de ficarem denegridos pelo contato com as pessoas desonestas. Ostentar um cargo não torna o homem virtuoso e 
digno. O verdadeiro respeito é alcançado por quem é virtuoso, pois a posse da virtude é um valor por si mesmo, e é humilhação implorar pelos cargos, ensina Boécio. A dignidade deve ter valor por si mesma, não ficando à mercê de falsas opinióes de outros homens e povos. Como as dignidades provenientes dos cargos náo têm valor em si mesmas, porque o recebem de algo exterior, então elas não possuem (e não produzem) o verdadeiro respeito e honorabilidade.

O poder político (prosa 9) não é suficiente para levar à felicidade e é incapaz de conservar a si mesmo. É só verificar a história da ascensão e do declínio dos Impérios para perceber o perigo em manter o poder. $\mathrm{O}$ tirano, por mais forte que pareça, sabe que pode perder sua condição. Vive preocupado e com medo. Cerca-se de guardas para garantir o viver em segurança e deter o poder. No entanto, ele não pode realizar o que deseja por si e necessita do auxílio de outros. Torna-se dependente e com poderes relativos, isto é, menos poderoso do que parecia. Nada mais atual na comparaçáo com o poder político dos estados democráticos e suas mazelas.

Os cortesãos, como Sêneca e Papiniano, que seguidamente são "[...] as vítimas preferidas dos soberanos", também são lembrados pela Filosofia, que pergunta a Boécio (prosa 9): "Que espécie de poder entâo é esse que amedronta os que o têm, que é exercido com risco e do qual não podemos nos desfazer quando desejamos?”. Na continuação, o autor faz referência aos falsos amigos "[...] que conquistamos não com o mérito, mas com a Fortuna", os quais não são garantia de ajuda nos infortúnios. Ao contrário, podem-se tornar inimigos, mesmo dentro de casa. Parece ser uma clara alusão aos falsos amigos do próprio Boécio. Talvez tivesse em mente a Cassiodoro. De qualquer maneira, o que chama a atenção é a atualidade dessa reflexão ético-política, instigando a repensar o próprio ideal de educação e de cidadania que queremos.

Na prosa 11, é a vez da glória obtida pela superficialidade da opinião pública através da popularidade, que é emotiva, passageira e restrita a alguns povos. A glorificação popular, na maioria das vezes, não é fruto de méritos verdadeiros a partir de sua consciência, porém, da glorificação exterior, ou seja, avaliando-se o seu valor pelo metro da popularidade. Dentre as virtudes romanas, a glória era a mais interessante e constantemente procurada, mesmo sendo a mera glória mundana, acompanhada de tormentos e medo em perder a paz. Frisa a Filosofia que, "[...] se há algo de bom na nobreza hereditária, a meu ver isso se resume ao fato de os herdeiros poderem ser dignos dos méritos de seus ancestrais". 
Como último caminho, e que igualmente não conduz à felicidade, a Filosofia trata dos prazeres corporais. Na prosa 13, tais prazeres, além de momentâneos, são o que temos em comum com os animais e nos levam à escravidão e à depreciação do caráter. Nesse sentido, acompanhando Aristóteles, diz a Filosofia, ironicamente: "Por que então não afirmaríamos que também os animais conhecem a felicidade, uma vez que todos os seus esforços tendem à satisfação de uma necessidade física?”. Embora haja esse lado negativo dos bens corporais, reconhece Boécio, nas palavras da Filosofia, a importância dos prazeres facultados pela mulher e pelos filhos, mas lembra que, para a tranquilidade e a paz de espírito requeridos no contemplar, é mais feliz aquele que está longe de questóes e preocupaçóes cotidianas nas relaçóes familiares: "A esse respeito, partilho o conselho de meu Eurípides, que diz que, quando não se tem filhos, então há a possibilidade de libertar- se do infortúnio".

Em resumo, esses bens aparentes estão mesclados de males, trazendo à tona, ao buscá-los, mesmo na união perfeita de todos os bens e como ideal e caminho da felicidade prometida, o lado negativo que acompanha cada uma dessas soluçóes externas à alma. O homem encontra-se prostrado demais sobre as seduçóes das coisas sensíveis, as quais são efêmeras, fugazes, impossibilitando-o de tornar-se feliz. Isso ocorre, principalmente, ao fixar-se na aparência do belo que, na verdade, traduz as ideias de coisas corruptíveis, imperfeitas, que se transformam e morrem. Admiração maior que a dada pelo céu e seus atributos deveria ser a dada pelo princípio racional que dirige esse mesmo céu. Seria necessário que "[...] os homens tivessem olhos de lince”, salienta a Filosofia, repetindo Aristóteles, para ir além e romper essa redoma de aparências que é resultado não da natureza, todavia, da "[...] fraqueza da vista dos que te olham".

Na prosa 17, a Filosofia vai iniciar o caminho positivo de mostrar ao seu discípulo náo mais o que significa a falsa felicidade, mas a verdadeira felicidade, cujo antídoto contra o erro humano está na própria definição de felicidade. Esses passos são construídos num diálogo maiêutico entre a Filosofia e Boécio, reconhecendo de saída que os bens que caracterizaram a falsa felicidade não cumprem o prometido. Os motivos desse fracasso estão em procurar a felicidade nas coisas exteriores, fracionadas e múltiplas, e não em um único bem simples, indiviso, perfeito, pleno, que contém em si e em uma só e mesma natureza a suficiência, a potência, o respeito, a fama e a alegria. Explica a Filosofia a Boécio: "E porque o erro humano divide o que é por 
natureza simples e indivisível, e transforma o verdadeiro no falso e o perfeito no imperfeito".

Nesse sentido, considerar que a felicidade deve ser encontrada num bem "uno e simples por natureza", que engloba tudo numa só coisa, todas as aspiraçóes humanas que não resultam das coisas exteriores, sejam elas fracionadas ou juntas, mas da perfeição suprema desse Sumo Bem, em que a alma humana deve estar unida Nele, aponta para a ideia do Uno de Plotino e do Mundo das Ideias platônico como o lugar em que se possa encontrar e realizar a felicidade. A Filosofia (prosa 17) pergunta: "Esses bens mortais e perecíveis têm, segundo pensas, a menor possibilidade de te proporcionar um tal estado de felicidade?”.

O resultado alcançado nesse diálogo da Filosofia com Boécio foi o de compreender qual é a verdadeira felicidade e quais são as falsas aparências, apontando onde essa condição de ser feliz pode ser encontrada, isto é, na morada do Bem Supremo. Conclui Boécio (prosa 17): "Invocar o Pai de todas as coisas, pois esse é o ritual com que se começa todas as coisas". Assim, observa De Boni (1995, p. 522), "[...] a Filosofia reportando-se ao Timeu, entoa o célebre canto 18: 'O qui perpetuam mundi', que constitui o ponto axial não só do Livro III, mas de toda a obra”.

Já que a poesia 18 é o núcleo do pensamento de Boécio e da obra aqui reportada, convém reconstruir os seus principais pontos. Ao cantar "Ó tu, que governas o universo segundo uma ordem eterna, Criador da terra e do céu, que num momento da eternidade por tua ordem fizeste o tempo marchar pela primeira vez, o universo gira em torno de teu trono inabalável", deixa clara a existência da lei eterna e a ideia do Deus criador dos cristáos, tendo em vista a ausência de tal conceito de criação no pensamento grego e a introdução da história no tempo. Porém, ao falar de Deus como imóvel, retoma a ideia aristotélica expressa no livro Metafísica, do primeiro motor imóvel, do movente não movido que é puro ato e é causa do movimento subsequente. Por sua infinita bondade, prossegue: "[...] que te inspirou a ordenar a matéria informe", o que revelaria imperfeiçáo por atuar diretamente sobre a matéria e relativizaria a bondade pela interferência do mal.

As ideias platônicas se evidenciam na produção "[...] do modelo celeste, trazes mentalmente em ti um mundo belo, Tu que és pura beleza, lhe dás forma segundo tua imagem e descobres de sua perfeição formas perfeitas”. Essas noçóes de beleza reportam ao belo de Platão, de Santo Agostinho e, com 
um toque místico, essas essências ideais foram hipostasiadas e unificadas no Uno de Plotino.

$\mathrm{Na}$ sequência da poesia, aparecem os fundamentos da cosmologia grega, em que a uniáo e a harmonia entre os quatro elementos de Empédocles são assim distribuídos pela mão divina. A terra, a água, o ar e o fogo, dizia Aristóteles, tendem para seu lugar natural, e ele explica pelas noçôes de ato e potência o mundo celeste, composto pelo quinto elemento chamado éter, que se movimenta circularmente; além disso, destaca o mundo terrestre, em que os quatro elementos se encontram sujeitos à geraçáo e corrupção em movimentos retilíneos. A harmonia e equilíbrio dos elementos são fundamentais para evitar os excessos, os quais causariam a desordem da ordem (kosmos).

Nesse movimento constante, continua a poesia: "Tu dispóes no meio os elementos de tríplice natureza”, isto é, vegetativa, sensitiva e racional, “[...] e Tu o dispersas harmoniosamente". Almas espalhadas e divididas pelo céu e pela terra com a missão de completar "[...] um duplo círculo de enorme extensão" de saída e de volta, "[...] voltando-se sobre si mesmo, retorna sempre a seu ponto de partida e no seu dúplice curso". Pela lei divina, "Tu os fixas no céu e na terra e, segundo tua benevolente lei, Tu os fazes voltar a ti uma vez purificados”. Essas passagens parecem ser uma referência ao estoicismo.

$\mathrm{Na}$ parte final da poesia, em tom de súplica, parecendo uma oração, não deixa dúvidas sobre o que seja o verdadeiro bem: "Dá ao meu espírito, ó Pai, o consentimento de aproximar-se de teu augusto trono; Concede-lhe visitar a fonte do bem, onde se encontra a luz, E não mais olhar para mais nada além de tua alma”. Essa sublime morada pode ser tanto cristã como platônica ou neoplatônica. O termo pai é o Deus cristão, embora os gregos chamassem os deuses de pai e, no estoicismo, este seja um conceito central. E o ideal de contemplação, no sentido muito mais de contemplatio do que de speculatio, fica registrado no "[...] náo mais olhar para mais nada além de tua alma". $\mathrm{O}$ desejo de libertar, enquanto homem, a sua alma dos prazeres ou sofrimentos do corpo, é marcante.

E, para finalizar, nesta invocação da poesia, fica evidente o ideal filosófico neoplatônico permeado pelo espírito cristão de libertar-se do mal:

Afasta as nuvens e o peso da massa terrestre, e que resplandeçam todas as luzes! Pois tu és a serenidade, Tu és o repouso e a paz dos justos: e contemplar-te é o seu fim; Tu, origem, condutor e guia, eis que vieram ao mesmo tempo o caminho e a chegada. 
A partir dessa poesia em diante, Boécio aborda o conhecimento racional a respeito de Deus, isto é, o texto se transforma em um tratado de Teodiceia. Vai tentar demonstrar a existência do verdadeiro bem, ou seja, Deus, que é o Bem Supremo através do argumento da perfeição, ou seja, do conhecimento ascendente do imperfeito para o perfeito e, também, por emanação, no sentido atual de criação, e não no sentido clássico de panteísmo. O que Boécio quer é provar a existência do Sumo Bem, que é Deus.

Sendo a felicidade o Bem Supremo do homem, e se o Bem Supremo não pode ser outro senão Deus, então Deus é a própria felicidade. Deus é simplicidade e infinita perfeição e bondade que reúne e ordena todas as coisas por si mesmo, através da providência divina, fazendo com que tudo tenda para um fim e que possam ser tidos todos os bens parciais e exteriores como bens por participarem da unidade do bem maior, que é o Bem Supremo. Felicidade, Bem Supremo, Uno e Deus se identificam, e cabe ao homem, por intermédio da filosofia, chegar a essa felicidade que, em última análise, por participação, se torna Deus, ao atingir a divindade. Só em Deus se encontra a verdadeira felicidade. De fato, ser feliz é adquirir divindade e, por isso, qualquer homem feliz é Deus, embora exista apenas um só Deus por natureza.

\section{CONSIDERAÇÓES FINAIS}

Segundo Boécio, como vimos acima, para poder chegar ao Bem Supremo, que é o princípio, o sustentáculo, o guia e o fim, é necessário trilhar o caminho náo mais das coisas exteriores, materiais, as quais são instáveis, mas a via da alma humana. Buscar na própria interioridade da alma humana e penetrar nos fundamentos, para descobrir a verdade, significa a volta à morada do Pai. Não pode ser o mero renunciar às verdades do mundo exterior, como na postura cética antiga, mas, além de isolar-se das coisas materiais, é necessário voltar-se para dentro de si próprio, no seu interior, e ficar a sós, porém com Deus. Esse itinerário da interioridade, defendido com fervor também por Santo Agostinho, dois séculos antes, é um dos pilares da educação cristá e o primeiro vestígio da construção da subjetividade moderna.

Pôr-se no verdadeiro caminho da filosofia, em sua reflexão ética para retornar ao mundo da felicidade, significa aprender a viver, a recordar e a recuperar a memória que guardava toda a carga conceitual de sua sólida formação, no caso de Boécio, ofuscada pelos falsos bens e pelo sofrimento causado pela perda deles, na medida em que fora acometido por uma afecção 
doentia. Assim, conhecendo o Sumo Bem e sabendo aonde e como chegar até ele, isto é, aprender a "cuidar" de si mesmo, o homem (Boécio) encontra-se em condiçóes de ser feliz, de voltar para a sua verdadeira pátria. $\mathrm{Na}$ verdade, nada do que a Filosofia ensina a Boécio é novidade para ele, uma vez que a sua memória armazenava o conhecimento e a sabedoria aprendidos, desde a infância, sobre como viver uma vida verdadeiramente ética. O homem sábio não se deixa enganar ou perturbar, porque sabe com o que não vale a pena se importar. É o ideal da sabedoria prática, do amor à sabedoria, da busca do saber viver uma vida serena, digna e feliz, educando-se e cuidando de si mesmo. O drama de Boécio é que sua alma adoeceu, ao que parece não por vontade própria, pois esqueceu-se dos ensinamentos filosóficos aprendidos.

Ao despertar via memória o conjunto de conhecimentos, de valores e razões que estavam esquecidos, Boécio os retomará e serão condição de possibilidade da transformação do seu olhar interior e de todo o seu ser em nível teórico, já que o prático a morte lhe negou. O resultado foi Boécio perceber que, na verdade, não perdeu nada de valor e não há do que se lamentar, visto que o véu das ilusôes em que vivia antes da prisão se dissipou sob o consolo da Filosofia. Novamente dono de seu pensamento e de seu destino, liberto da opressão subjetiva da infelicidade que atormentava seus sentidos e seu coração, Boécio procurou racionalmente tranquilizar a sua razão, procurando no interior de sua alma a verdade de Deus. A verdadeira vida não é aquela que está à mercê da Fortuna, e isso ele tinha aprendido desde jovem. Todavia, como esqueceu e mergulhou nos falsos bens, mesmo que tardiamente, ele voltou a recordar e, assim, reconquistar a sua liberdade. Essa reconquista é da própria dignidade humana, enquanto pessoa humana e mortal, mas constituída de uma dimensão racional que lhe possibilita se autodeterminar, ter o controle de si, escolher e praticar o bem e ser feliz como partícipe desse divino, e mesmo o de transcender sua condição rumo a Deus.

Pela "hermenêutica" de aprisionado e torturado fisicamente, Boécio refletiu sobre sua condiçáo pessoal, a qual apontava duas possibilidades: (1) continuar prostrado e morrer como condenado; (2) ou recuperar o domínio racional de si sobre as paixóes corporais e, assim, livre intelectualmente, morrer sereno e dignamente como homem e esperar viver como substância separada. É a Filosofia, compreendida platonicamente enquanto cristão, que conduz Boécio a acreditar que não há motivos para temer os infortúnios da vida, as prisóes e torturas, porque a verdadeira liberdade está na interioridade da alma e, portanto, o mundo náo é governado pela roda da Fortuna. 
SANGALLI, Idalgo José. The conquest of happiness through philosophy: the example of Boethius. Trans/Form/Ação, Marília, v. 37, n. 3, p. 65-86, Set./Dez., 2014.

\begin{abstract}
This article analyses ethics and education in Boethius' De consolatione philosophy of Boethius. We seek to comprehend the search for happiness as expounded in Book III of that work. Boethius takes up the idea that all men wish to reach the final good, which is identified as happiness. Lost in the fragmented multiplicity of external goods and passions, men should search - by the path of philosophy and without resorting to religion - the one true good: God. These considerations indicate the path of human life and the need for one to "learn to live" an ethical life, freeing oneself from the passions of the body that sicken the soul.
\end{abstract}

KEYWORDS: Ethics. Happiness. Supreme Good. Destiny. False goods.

\title{
REFERÊNCIAS
}

ARISTÓTELES. Ética a Nicômaco. 2. ed. Brasília: Ed. UnB, 1992.

BOÉCIO, A. M. S. A consolação da filosofia. Prefácio de Marc Fumaroli, traduzido do latim por Willian Li. São Paulo: Martins Fontes, 1998.

COELHO, Cleber D. O homem, o bem e a felicidade na consolação de Boécio. Curitiba: CRV, 2014.

COURCELLE, P. La consolation de Philosophie dans la tradition littéraire: antécédents et postérité de Boèce. Paris: Études Augustiniennes, 1967.

DE BONI, Luis A. Tomás de Aquino e Boécio de Dácia: leitores dos clássicos a respeito da felicidade. Veritas, Porto Alegre, v. 40, n. 159, p. 517-531, set. 1995.

FRAILE, G. Historia de la filosofia: Grecia y Roma. 2. ed. Madrid: BAC, 1965.

GILSON, E. La filosofía en la edad media: desde los orígenes patrísticos hasta el fin del siglo XIV. 2. ed. Madrid: Gredos, 1985.

JAPIASSU, H. Um desafio à filosofia: pensar-se nos dias de hoje. São Paulo: Letras e Letras, 1997.

KENNY, A. Uma nova história da filosofia ocidental. São Paulo: Loyola, 2008. v. 2: Filosofia medieval.

LE GOFF, J. História e memória. Trad. Bernardo Leitão et al. Campinas: UNICAMP, 2003.

PIEPER, Josef. Filosofia medieval y mundo moderno. 2. ed. Madrid: Rialp, 1979.

REALE, G.; ANTISERI, D. História da filosofia: antigüidade e idade média. 2. ed. São Paulo: Paulinas, 1990. v. 1.

Enviado em: 15/09/2014

Aceito em: 06/10/2014 
SANGALLI, I. J. 